\title{
Key and the use of Moroccan function words in Dutch internet discourse
}

\begin{abstract}
In the Dutch used by Moroccan heritage youth one often encounters Moroccan Arabic and Berber function words inserted in otherwise Dutch discourse. This article studies a subset of these function words within the internet forum chaima.nl, a forum geared towards adolescent girls and young women of Moroccan descent in the Netherlands and Flanders. It aims to show that one major function of the insertion of these function words is to key the utterance as (self-)ironic and not-toserious.
\end{abstract}

\section{Samenvatting}

In het Nederlands van jongeren met een Marokkaanse achtergrond komen vaak MarokkaansArabische en Berberse functiewoorden voor die zijn ingevoegd in een anderszins volledig Nederlandse tekst. In dit artikel wordt een aantal van deze functiewoorden bestudeerd binnen het internet forum chaima.nl, een forum voor jonge vrouwen van Marokkaanse afkomst in Nederland en Vlaanderen. Het artikel probeert te laten zien dat het gebruik van deze functiewoorden de uiting als (zelf-)ironisch en niet al te serieus kan kenmerken.

Keywords: Moroccan Dutch; Conversational key; Youth styles; Youth languages; Internet discourse

\section{Introduction}

In 2012, ${ }^{1}$ a Dutch-Moroccan girl from Amsterdam with the alias @Amazigh-Chick posted the following comment on the Moroccan-Dutch internet forum chaima.nl. The post is part of the section Verhalen 'stories', where members post their creative writing. Such stories are published as feuilletons, and other members are expected to cheer for the poster and encourage her to carry on writing.

Oepppaaaaaaaaaaaaaaaaaa wajoow me moeder wilt me naar gekken tehuis sturen wollah ik zit bhel shi zombi achter de laptop om te kijken of je al een vervolg had geplaatst!!

'Up! Wow (wayyaw), ${ }^{2}$ my mother wants to send me to the madhouse, lo! (wa!lah) I am sitting like (bhal) some (ši) zombie behind the laptop looking whether you already posted a sequel.' [chaima.nl; @Amazigh-Chick; 19/10/2012]

The language in this post is mostly colloquial Dutch, but it has a number of special features. The initial word Oepppaaaaaaaaaaaaaaaaaaa, with expressive letter repetition (Darics 2013), is a

\footnotetext{
${ }^{1}$ I wish to thank Khalid Mourigh, Jacomine Nortier and Margreet Dorleijn for their important input and critical discussions. I greatly profited from the comments of two anonymous reviewers and of the editors of the journal. Of course all responsibility for the argument, and all the errors and flaws that are part of it, lies solely with the author. The article was written in the context of the European-funded project AThEME: Advancing the European Multilingual Experience. All internet data studied here can be accessed by means of an automatically approved registration, obviously meant to protect the site from robots.

${ }^{2}$ The transcription of Moroccan words follows the phonemic structure of Moroccan Arabic and Tarifiyt Berber. Following practices in the field, $\breve{s}$ stands for []], $\check{z}$ for [3], $h$ for [ $\hbar]$, and, in Berber, $\check{r}$ for [r]. Other consonants with a dot underneath are pharyngealized. The fonts and colors of the original posts are not taken over in the citations. In the English translations, interpunction has been added, and no effort has been made to produce equivalents for non-standard orthographies. The use of English insertions in the posts is signaled by italic font in the translations.
} 
marker of appreciation which is typical of Moroccan Dutch internet writing among girls. It is derived from English up (in the sense of 'thumbs up'), and alternates with up, uppa, oep and similar forms.

Most remarkable about the post is its use of four different Moroccan words. Two among these are expressive interjections. Wayyaw signals surprise, bewilderment, enthusiasm and many other shades of expressivity, not unlike English 'wow'. Wa!lah is essentially an oath formula 'by God', and is regularly used as such in Moroccan Dutch. Both in Morocco and in immigration contexts, it can also convey strong assertion (Procházka 2012: 394-397; Cheshire, Nortier \& Adger 2015: 6); for lack of a better equivalent, it will mostly be translated by 'lo!' in the examples. The other two Moroccan elements are function words. Bhal is a preposition meaning 'like' and ši is an indefinite marker translatable as 'some'.

@Amazigh-Chick is a prolific poster on the forum, and many of her posts are very different. An example of this is the following explanation, posted two weeks later, about a story that she is posting herself, and which has no Moroccan elements:
Bedankt voor het uppen dames!!!!!
Het spijt me heel erg maar ik zal vandaag ook niks kunnen plaatsen.
Ik ga weg, en ik zal de hele dag niet thuis zijn.
Nogmaals mijn excuses, en ik hoop dat jullie begrip hebben!
'Thanks for writing "up", ladies!
I am very sorry, but today I will not be able to post anything again.
I am leaving and I will not be home for the entire day.
My apologies again, and [I] hope you'll be understanding!' [chaima.nl; @Amazigh-Chick; 3/11/2012]

This raises the question why @Amazigh-Chick uses so many Moroccan elements in some posts, and so few in others. The two examples were posted on similar parts of the forum, with a similar audience and a similar subject. Therefore, there is no reason to assume that @Amazigh-Chick is playing out different personas or identities in the two posts. There is, however, one important difference. The first post is self-ironic and not meant to be taken very seriously. The second post is an apology which - although about a light subject - is certainly meant to be serious. There seems to be a major difference, thus, in key, that is, "the tone, manner, or spirit in which an act is done" (Hymes 1974:57). As formulated by Hymes, "[a]cts otherwise the same as regards setting, participants, message form, and the like may differ in key, as e.g., between mock: serious or perfunctory: painstaking." (Hymes 1974:57; cf. also Bauman 1975; somewhat differently, Goffman 1974, chapter 3). Ever since Hymes' seminal work, key (or keying) has been an important concept in the analysis of communication, even though it may have drawn less attention than other subjects. It figures, for example, as an important contextualization process in Nikolas Coupland's model of style and social meaning (Coupland 2007: 114).

The present article will argue that the use of certain function words with a Moroccan etymology is a way of keying the message as slightly ironic, and not to be taken very seriously. As such, it has a different focus from analyses of Moroccan Dutch youth language and multiethnic youth varieties in general that emphasize the expression and creation of identities (e.g. Nortier \& Dorleijn 2008; Nortier \& Dorleijn 2013: 233; Svendsen 2015: 12ff.; Kießling \& Mous 2004; cf. however Auzanneau 2009: 880ff. on the 'langue des cités' for an approach similar to the one taken here). ${ }^{3}$

\footnotetext{
${ }^{3}$ For a short but enlightening analysis of the relationship between multilingual speech and social identities, see Auer (2005). Jürgen Jaspers' works on language use by Antwerp youngsters with a Moroccan background takles a different approach (among others, Jaspers 2004, 2006, 2011). The function word insertions that are the
} 
There is of course no reason to assume that only key would be expressed by using Moroccan function words in Moroccan Dutch discourse. As stressed by Nortier \& Dorleijn (2008), identity characteristics like heritage group and age are no doubt indexed by such usage. In order to control for this, I will use a corpus where many of the latter potential indexes are neutralized, in the sense that participants are similar as to their social embedding, and that language use would not be expected to differentiate identity-type social meanings ${ }^{4}$ within this specific context. The corpus in case is a Dutch/Belgian internet forum for adolescent girls and young adult women with a Moroccan background, chaima.nl, which will be introduced in more detail below.

The article focuses on a small number of Moroccan function words, that are relatively common in the corpus: markers of interrogation, indefinite determiners, and the similative preposition bhal 'like'. This is only a subset of the Moroccan function words that occur on the forum. The choice for these elements instead of a larger set is based on two considerations. In the first place, the chosen function words are not inherently expressive, different from interjections like wayyaw and wa!lah in (1). Expressive vocabulary is in itself a way to key an utterance, and it would be difficult to tease apart the key conveyed by choosing expressive words and the key conveyed by choosing Moroccan vocabulary. In the second place, the chosen elements are structurally similar in that they are involved in the inner syntax of the clause, and thus represent a much greater intrusion on the Dutch system than, for example, preclausal utterance modifiers (Matras 1998) such as muhim 'well'. More in general, there is no reason to assume that all Moroccan elements would have the same keying effects, in fact, my personal impression is that utterance modifiers are brought into action in different ways and with different effect than the elements I will focus upon here.

A (self-)ironic, not-so-serious key can also be suggested otherwise. Thus, in written Moroccan Dutch internet discourse, it can be indicated by pictographic ${ }^{5}$ and written representations of chuckling and laughter, as will be evident in a number of the examples given below.

In this article it will be left open to what extent the phenomenon studied here is part of a larger unit, such as Moroccan Flavored Dutch (Nortier \& Dorleijn 2008) or an emerging Moroccan Dutch ethnolect (Hinskens 2011, Van Meel 2016). Only a detailed study of the uses of all the phenomena subsumed under these more comprehensive headings can ascertain whether we are indeed dealing with a coherent unit or not.

The present study is qualitative in nature, and its research methods are similar to what has been described as guerilla tactics in internet ethnography (Yang 2003: 471, Androutsopoulos 2006: 527), exploring the website by means of search quests, tracking posters' posts and profiles within the forum, reading extensively through promising and less promising threads. Different from Yang and Androutsopoulos, I have not interacted myself with members of the chaima.nl community.

\section{The linguistic elements under study}

People with a Moroccan background constitute one of the larger heritage groups in Belgium and the Netherlands. Large-scale immigration from Morocco to these countries started with labor migration in the 1960s, mainly by young men. Later on, they were followed by their families (Crul \& Doomernik 2003; Cottaar, Bouras \& Laouikili 2009). Although migrants came from all over Morocco, the large majority were from the northern part, mostly from the region called the Rif, roughly the mountain range along the eastern half of the Moroccan Mediterranean coast. Morocco is a multilingual country, in which both the regional Arabic vernacular, Moroccan Arabic, is used, and several Berber languages. In the Rif, the major language is Tarifiyt Berber. Berber and Arabic are only very distantly

subject of the present article are not treated by Jaspers, and may have been absent in the speech of the group he studied.

${ }^{4}$ This does not rule out, of course, that sometimes keying is part of identity work (Özcan et al. 2015: 232-233).

${ }^{5}$ For a list of emojis on chaima.nl and their names, see http://www.chaima.nl/misc.php. 
related, but due to a thousand years of language contact, many lexical and grammatical features are shared (Kossmann 2013).

Within the Dutch and Belgian Moroccan communities, both Tarifiyt Berber and Moroccan Arabic play an important role. Morocco is characterized by asymmetrical bilingualism: almost every speaker of Berber also knows Moroccan Arabic, while native speakers of Moroccan Arabic hardly ever have knowledge of a Berber variety. The situation in the diaspora is different, and there are many people who speak Berber, but do hardly know Moroccan Arabic. In addition, in the Netherlands and Flanders, Dutch plays a major role, not only in dealings outside the community, but also within. This has a long history - at least in the Netherlands - and already in the mid 1980s, half of the young Moroccans interviewed reported using Dutch among siblings (De Ruiter 1989: 58).

Moroccan elements that are used in Dutch discourse come from Moroccan Arabic and from Tarifiyt Berber, abbreviated in the following as "Arabic" and "Berber". Especially with utterance modifiers, the two languages often use the same words, e.g. muhim 'well', zaৎma 'you know' (Boumans 2003). In other cases, both the Arabic and the Berber form are encountered in Dutch discourse. Finally, with a few elements, only the form in one of the Moroccan languages regularly appears in Dutch discourse, even though there exists an equivalent in the other language.

In this article, focus will be on three types of function words: indefinite determiners, the similative preposition/conjunction, and markers of yes/no questions. For the sake of reference, the elements under investigation will be abbreviated as IND-SIM-INT.

(a) The use of the Moroccan indefinite determiners ižžan idžan (< Berber) / waḥad waḥd (< Arabic) 'a' and šan šin (< Berber) / ši (< Arabic) 'some'. The latter can also be combined with number expressions where it can be translated as 'about'. Example:

(3) \{context: A topic entitled DatingTopic..., in which members are asked to give information about male family members available for marriage. The entire topic is in a very unserious key; in this post, key is also marked by letter repetition and laughter.\}

Nahouuuuu, ik heb ijen broer die wilt echt graag een serieuze meisje waarmee ie snel mee kan trouwen. Hij zegt altijd tegen mij: Heb je nog niks voor mj gefixt? Shien goeie vriendin van jou ofzo? Hahaha.

'Well, I have a (ižžan) brother who really wants a serious girl with whom he can marry soon. He always tells me: Haven't you arranged anything for me yet? Some (šin) good friend of yours or something like that? Hahaha.' [chaima.nl; @Rifjunk, 19/10/2009]

(b) The use of the Arabic similative preposition/conjunction bhal (less frequently its dialectal variant fhal) 'like, as if'. Its Tarifiyt Berber equivalents am and aməšnaw are hardly ever encountered. ${ }^{7}$

(4) \{context: A topic about how many days it takes the family to reach Morocco when going on vacation. The key is also indicated by the :hihi: "chuckles" emoji.\}

Wash rijd je pa op zen gemak oela bhal mijn vader die vliegt naar marokko(6)

'Waš (question marker) does your dad drive at his leisure or (ula) like (bhal) my father, who races to Morocco? @il' [chaima.nl; @LaBellaMtiwia, 26/3/2007]

\footnotetext{
${ }^{6} \breve{S} a(n)$ and $\check{s} i(n)$ are dialectal variants in Tarifiyt Berber. From a Berber point of view, these forms are constructions of a pronominal element ša/ši with the genitival preposition $n$ 'of'. In our corpus, they are always written as a whole, and seem to function as single morphemes.

${ }^{7}$ Bhal has been borrowed into some peripheral varieties of Tarifiyt Berber (Kossmann 2000: 111).
} 
(c) The use of yes/no interrogative sentences introduced by the Arabic marker waš. The more or less equivalent Berber sentence-initial marker ma occurs only rarely (Kossmann 2016), e.g.:

(5) \{context: From the comments on a story. The story writer has been slow to write a new sequel and is urged to hurry up. Remark chuckling as a further marker of a not-so-serious key.\}

wesh ga je nog verder of niet.........

(hihihihiih, we wachten)

'Waš (question marker) are you going to continue or not?

(hihihihiih, we are waiting)' [chaima.nl; @jurkenmeisje, 27/9/2012]

(d) The use of the interrogative tags niy (< Berber), ma (< Berber), walla (< Arabic) (Kossmann 2016). Note that walla 'or' is etymologically unrelated to the assertive element wa!lah 'lo!, by God, absolutely'.

(6) $\quad$ Context: A post from the topic Boringg......., which is about the posters being bored and sleepy at that moment. The present post is an unserious proposition for a solution; the sentence given here is preceded by 20 instances of the emoji :nijn: "little rabbit".\}

Feestje bouwen wella?Gaat de verveling misschien over?

[What about] throwing a party, or (walla)? Maybe the boredom will go away? 9 ' [chaima.nl; Layla_15; 5/5/2011]

The use of IND-SIM-INT features in Dutch speech is no doubt to a large extent conventional and not due to a dynamic process of code-switching, in which the choice of elements would be basically free. There are two major reasons to assume this. The first reason is their frequency, as compared to similar Moroccan elements. Using the very rough tool of google hits (that misses many instances, and at the same time counts instances twice, because they are cited), one finds that within the website chaima.nl the indefinite ižžən/idžən/waḥad 'a' occurs 6,000 times, while šin/šan/ši 'some' has about 5,000 hits. The preposition bhal/fhal occurs about 1,500 times. The interrogative particle waš has about 2,500 hits. On the other hand, similar elements in the heritage languages, such as the Arabic definite determiners had 'this' and dak 'that', and the Berber post-nominal deictic clitics $-a$, -in and -anni, are almost never encountered. ${ }^{8}$

The second argument concerns the choice of heritage language. In the Moroccan Dutch community both Berber and Arabic are spoken. There is, however, no one-to-one relationship between the heritage language of the poster and the origin of the inserted elements. Thus, for example, in the case of @Amazigh-Chick, literally 'Berber girl', the alias strongly asserts a Berber identity, while the inserted elements in her posts are mostly from Arabic (e.g., in example 1). When writing full sentences in the heritage language, she uses Berber. Anecdotal confirmation that this is also the case in spoken discourse was found in a street conversation Khalid Mourigh and I had with a young Dutch-Moroccan Berber woman in Amsterdam (December 2015), who used the Arabic indefinite marker in 'wahd buurvrouw', 'a neighbor'. One also encounters constructions in which Berber and Arabic elements co-occur, for example, the following post where Arabic bhal is used alongside Berber ižžən. Note that, according to other posts, @missamazigh has her roots in a region (Ayt Weriaghel) where the form bhal is not part of the local variety of Tarifiyt Berber.

\footnotetext{
${ }^{8}$ Pace Nortier \& Dorleijn (2008: 130). The use of post-nominal Berber deictics in otherwise non-Berber contexts is common in French-Kabyle code-switching, cf. Mettouchi (2008).
} 
(7) \{context: A topic about weird behavior by oneself. Sponge Bob is a cartoon figure who has a loud, and highly irritating way of laughing.\}

EN ALS IK DE SLAPPELACH HEB DAN LACH IK BHAL IZJEN SPONGEBOB.

'And when I have a fit of laughter I laugh like (bḥal) a (ižžən) Sponge Bob.' [chaima.nl; @missamazigh; 19/6/2010]

This is also the case in interrogative constructions, that often combine the sentence-initial Arabic question marker waš with the sentence-final Berber tag niy (cf. Kossmann 2016).

Finally, the IND-SIM-INT elements under consideration are not typically found in DutchMoroccan Arabic code-switching as it was documented in the late 1980s and early 1990s. Neither Nortier (1990), nor Boumans (1998, based on recordings from 1991-1992) observed instances of Moroccan indefinite determiners within Dutch discourse. Boumans noted a few cases of the interrogative marker waš (1998: 331) in his corpus, but analyzed them as "rephrasings of the question in Dutch". Thus, the insertion of IND-SIM-INT cannot be considered typical for code-switching between Dutch and Moroccan languages. On the other hand, in lexical borrowing in general, the take-over of indefinite article-like elements is also highly uncommon (Matras 2009: 216), so the pattern found here is unusual anyhow.

Moroccan-Dutch forums have archives, some of which go back to the beginning of 2001 (maroc.nl). The earliest attestation of inserted Moroccan IND-SIM-INT elements that I could find dates from July 2002:

(8) \{context: The topic starter, @crazy2000, opens and signs his question by the Islamic greeting s-salam Ylikum. @dodi_vega, ridicules this choice of expression, either because it does not fit the further profile of @crazy2000, or because it was used as a signature; in Moroccan usage, s-salam Slikum is not used to close an encounter. @crazy2000's posted his question at 8:51 in the morning and @dody_vega suggests that he was not yet really awake at that time.\} ben je nog aan het slapen wella..?????? shie droom gehad niegh.. hahaha. crazy2000 en salam Alikom?? hahahah coolz>. ga ga koffie drinken jij..

'Are you still asleep, or (walla)? Did you have some (ši) dream, or (niy)?' Hahaha. @crazy2000 and s-salam Slikum? Hahahah coolz>. Go, go drink coffee, you.' [maroc.nl; @dodi_vega; 15/7/2002].

This post is not only interesting as an early attestation, but also because the poster combines Arabic and Berber elements, even using two alternative tags, one from Arabic (walla) and one from Berber (niy). One also remarks that the post is clearly meant to be unserious, as shown by laughing, repetitions of punctuation marks, and the choice of emojis; this key is also acknowledged explicitly by another poster later on in the thread. As far as I can see, there is no major change in usage of the INDSIM-INT elements on internet fora between 2002 and now.

Written Internet discourse is in many ways different from spoken discourse (Dorleijn 2016a: 10-12), and in some internet communities, playing with foreign elements has been identified as specific to computer-mediated writing (Jaworska 2014). Therefore it is a highly relevant question to what extent the insertion of Moroccan function words is restricted to written computer-mediated communication, or that it reflects usage patterns in spoken interaction (cf. Dorleijn 2016b). The study of spoken corpora, such as the Gouda corpus (Mourigh 2015-2016), and a cursive study of filmed conversations as found on the Internet (esp. on youtube.com) shows that Moroccan IND-SIM-INT elements also appear in spoken discourse. Thus, in a street interview recorded by the Moroccan Dutch comedian Salaheddine, an adult man describes his experience with his father when coming home late as an adolescent: 
(9) \{context: The sentence is part of a short street interview about how fathers react to their sons coming home late. The general key is very light, the experiences being cast as funny adolescence memories. The interviewee recounts how he entered the house late one night.\} De deur gaat open, het is donker; ik doe de deur dicht - en ineens kreeg ik waḩad vlakke hand, keihard, recht in mijn gezicht. [interviewer laughs]

'The door opens, it is dark; I close the door - and all of a sudden I got a (waḩad) flat hand, really hard, right into my face. [interviewer laughs]'

[https://www.youtube.com/watch?v=xN1uAF97AI4; 2:31]

A further indication that the insertion of function words is a feature of spoken discourse in a written context is the lack of coherence in transcription. As Moroccan Arabic and Tarifiyt Berber have no generally known orthography, internet users come up with different solutions for writing sounds without simple equivalents in Dutch. This is also the case for the IND-SIM-INT elements. Thus, on the internet forum marokko.nl, I found 31 variant spellings for ižžan/idžzn and 57 variant spellings for wahad/wahd. If the use of these elements had its basis in written communication only, one would certainly expect more homogeneity.

Of course, this does not mean that the social meanings of the insertion of Moroccan elements need to be identical between spoken language and written computer-mediated discourse. As there are no studies of key in spoken Moroccan Dutch discourse, it is best to remain agnostic about this.

\section{The internet forum chaima.nl}

Within the Moroccan Dutch and Flemish community an important role is played by internet fora that are specifically geared toward this group (on diaspora internet fora, see the works by Jannis Androutsopoulos, e.g. Androutsopoulos 2006). There are general Moroccan Dutch fora such as maroc.nl and marokko.nl; fora with a strong Islamic ideology, such as zoubida.nl and ansaar.nl; fora relating to the regional origin of the users, such as rkempo.nl (for Berber speakers from the Rif) and ouarzazate.nl (for people with southern Moroccan origins); fora with regionalist ideologies, such as the Berber forum amazigh.nl (cf. El Aissati 2008; Lafkioui 2008); and many others. The majority of the members of these fora have a Moroccan background. In addition, some are Muslims from other communities, and, in fora that contain political and societal discussion, autochthonous Dutch people.

This article focuses on one of these fora, chaima.nl, a forum for Moroccan girls and young women, a target group symbolized by the all-pink lay-out of the website. The archives of the forum go back to 2006 and the forum is still active. The membership of the forum is remarkably homogeneous. It has very few active members of autochthonous Dutch origin, and over $95 \%$ of its users have a Moroccan background. The age range of the members is relatively restricted, mostly between 12 and 22 years old; ${ }^{9}$ the most active phase of forum life seems to be between 15 and 19 . An analysis of places of residence of some 700 members of the forum ${ }^{10}$ shows a distribution typical for Dutch and Flemish Moroccans: two thirds of the members are from the big cities Amsterdam, Rotterdam, The Hague, Utrecht and Antwerp, and, as far as information is given about this, they are mostly from poor neighborhoods well-known for their large percentage of inhabitants with a Moroccan background, such as Amsterdam Nieuw-West, The Hague Schilderswijk, Utrecht

\footnotetext{
${ }^{9}$ Based on information given by the posters about themselves in specific topics.

${ }^{10}$ Based on the personal information field "location" as well as information given by the posters in specific topics. While in a few cases the information may be deliberately deceptive, there is no reason to assume that this happens very often.
} 
Kanaleneiland, and Antwerp Borgerhout. Thus we can say that chaima.nl is a forum with a clear membership structure: Moroccan-descent girls between 12 and 22 years old with geographical and social backgrounds that are largely representative for the Moroccan community. The geographical background of the members in Morocco has not been studied in detail, but my impression is that this is also as one would expect in the Dutch and Flemish situation: most posters have a background from northern Morocco, and both Berber and Arabic speakers are active.

One of the characteristics of internet fora is the possibility for the members to remain anonymous to other users. Forum members have an alias (name) and an avatar (picture representing the poster), and forum information includes fields of personal information. In Moroccan Dutch fora, names are always anonymized aliases, and members never give their full name. Avatars hardly ever contain pictures of the members, and where they do, they are unrecognizable (e.g., only the back of the head scarf, or only the feet). The fields with personal information are mostly left blank or uninformative. The main exception to this is geographical information, both as regards regional background in Morocco and place of residence in the Netherlands or Belgium. Such information is often provided in the "location" field, but also surfaces in aliases (cf. Nortier 2016).

The anonymity to the outsider does not imply that members have no personal information about each other, or that they are reluctant to share such information with other members. Many members also meet outside the internet forum, and there is constant reference to "pm"s (personal messages) that allow members to communicate with each other personally. In many topics, personal information such as age, place of residence and first name are freely disclosed. In fact, it seems that anonymity is more meant to remain unknown to the outside world (one may think of family members or boys from the neighborhood) than to remain unknown to other members.

Like no doubt any other online community, chaima.nl has some overt and covert ideologies. Girls participating in the forum almost invariably present themselves as sensible, decent girls that attach great importance to being a good Muslim. Sexual relationships are considered only acceptable for married women, and, although posts sometimes refer to other Moroccan girls having lost their virginity before marriage, this is not discussed as a personal experience. Many girls wear the head scarf or consider starting to wear it, and no doubts are expressed about the necessity of following Islamic prescriptions, even though their exact content is often discussed.

Chaima.nl, like other Moroccan Dutch fora, contains many text types, among others free conversation about more or less light subjects; questions and answers on subjects such as Islamic life, body care, and relationships; news (mostly copied from other sources); Islamic knowledge (much of it copied from other sources); and creative writing. Text types are not strictly separate, and one single thread may contain different genres; a serious quest for advice may turn into light conversation; light conversation may be interrupted by Islamic admonition, etc. etc.

The language of chaima.nl is predominantly Dutch. Only occasionally Berber and Moroccan Arabic are used. One of the reasons for this may be that using one of the Moroccan languages would exclude from the audience members who only know the other language. Another reason is no doubt that writing and reading essentially oral languages such as Berber and Moroccan Arabic presents a major challenge to its users, and is only undertaken for specific ideological or practical needs. Moreover, it is very well possible that language choice simply copies patterns found in face-to-face communication (Dorleijn 2016b; Dorleijn \& Nortier 2009). The Dutch in chaima.nl is mostly colloquial Dutch, with major differences depending on the variety common in the place of residence of the poster.

\section{Key in chaima.nl}

Key is a difficult subject to study. In many cases, key is left implicit by the speaker or writer, and the audience has to reconstruct the key of a message from context and general expectations (Coupland 2007: 114); of course this may lead to major misunderstandings (Lampert \& Ervin-Tripp 2006: 53- 
54). While key may be suggested by certain linguistic elements - as is the main hypothesis here - this does not mean that such elements are obligatory. As a result, it is difficult to show that a certain linguistic feature correlates with a certain key. In order to make my point, I will take two approaches. The first is to look at text types (or genres) that cannot be reconciled with the specific key. The basic assumption being that the use of the Moroccan IND-SIM-INT elements conveys a (self-)ironic, not-soserious attitude to the utterance, the prediction is that they are infrequent in text types that demand for a serious key. In the following, one such serious type, advisory texts will be studied; after that, the difference between serious and humorous narratives will be shown. The second approach is to look at situations where the risk of misinterpretation is high, and where linguistic marking of the key is therefore highly functional. The situations that will be adduced are topic titles and mixed-key threads.

\subsection{Advisory texts}

Quests for advice on chaima.nl only rarely contain Moroccan IND-SIM-INT elements. One might assume that this is linked to a higher degree of formality in such sections, but this is far from evident. A case in point is the following example, where a post asking for advice has strong emotional content, but lacks any of the IND-SIM-INT elements studied here:

(10) \{context: The poster asks other forum members for advice how to go about a major row she has with a girl she knows.\}

ik heb volgens mij een groot probleem

nou waar zal ik beginnnen ik heb al een tijd ruzie met een meisje en nuu hoor ik van mensen dat ze een heel groep jongens op me gaat afsturen om mij inelkaar te slaan wat moet ik nu doen 2 (2)

$[\ldots]$

eigenlijk beg0n het heel klein de ramadan was begonnen en ze had lipgloss en maskara op en ik vroeg of ze ramadan heeft toen zij ze jaah hoezo toen zei ik je mag geen make-up met ramadan je hoeft het niet verkeerd op tevatten toen zij zei zovan het is helemaal niet haram en toen bleven we maar praten enzo todat ze begon te schelden en toen schold ik terug en daarna ging ze bij andere meisjes over me rodellen enzo en toen was ik er agter gekomen dus ik ging met haar praten en toen ging ze tegen me schreeuwen en enzo en toen kwam die nicht van het meisje en ze vroeg aan me waarom ik een heel groep meisjes op haar heb afgestuurd terwijl het helemaal niet zo was en die meisje waar mee ik ruzie heb beweerde van wel en toen kwam me neefje van der ook bij en had die meisje een stoot gegeven en ze werd heel boos en gisteren hoorde ik nog van een meisje en andere mensen dat ze morgen met een heel groep jongens komt om mij inelkaar te slaan

'I think I am facing a big problem.

Well, where shall I start; I have been quarreling with a girl for some time and now I hear from people that she is sending a whole group of boys towards me in order to beat me up. What shall I do?

[...]

Actually, it started rather small, Ramadan had started and she wore lip gloss and mascara and I asked her if she had [sic] Ramadan and she said: Yes, why? and I said: You are not allowed [to wear] make-up during Ramadan, don't take it wrong, and she said like: It is not forbidden (harām) at all, and then we continued to talk and things until she started to call me names, and I abused her back, and she started to gossip about me with other girls, and then I found out, so I went to talk to her and then she started to yell at me and things, and then came the female cousin of the girl and she asked me why I had sent a whole group of girls to 
her (scil. in order to beat her up), which wasn't true at all, but the girl with whom I quarreled claimed I had, and then my male little cousin of [sic] came also there and punched that girl, and she became very angry, and yesterday I heard from a girl and other people that she is going to come with a whole group of boys in order to beat me up.' [chaima.nl; @roosje; $8 / 10 / 2006]$

Note that the same poster freely uses Moroccan IND-SIM-INT elements in other posts.

Moroccan IND-SIM-INT elements are conspicuously rare in sections with Islamic advice, which, for example, do not present a single case of interrogative constructions with waš, walla or niy. Whenever IND-SIM-INT features pop up in these sections, they typically occur in posts that do not concern Islam as such. An example, with self-directed irony, is the following post from the topic "how many pins do you use for your head scarf?':

(11) Nu gebruik ik er shie 10 want serieus ik kan mijn hoofddoek nog steeds niet netjes vastpinnen en het wilt maar niet zitten.tips? 9

'Now I use about (si) 10, because, seriously, I can still not fasten my head scarf neatly and it does not remain in place. Any tips? $\$$ [chaima.nl; @Layla_15; 6/2/2014]

A similar case is found in the following fragment, which, though posted in a section on Islam, is more like casual gossip:

(12) \{context: The topic is about girls who pretend that they are pious by wearing the head scarf, but whose behavior is otherwise unfitting. In addition to the Moroccan elements, the post shows expressive respelling (Shaw 2008).\}

mechaa ik kwam vandaag uit tram en zag izjen mocroo mett hoofdoek en ze showde haar kont diee zoo groot wass wollah zo breed van hier tot tokioo jy weet niet

'But (maša) I got off the tram today and I saw a (ižžan) Moroccan with a head scarf, and she showed her ass that was so big, lo! (wa!lah) as big as from here to Tokyo, you can't imagine.' [chaima.nl; @romaissa83; 27/1/2010]

\subsection{Narratives}

On the forum, two types of narrative texts appear. On the one hand there are stories that are posted in the section Verhalen ('stories'), which are, with very few exceptions, serious first-person narratives. On the other hand one also finds - in many different parts of the forum - funny anecdotes. In the narrative parts of the serious stories - that is, those parts that are not dialogues -, Moroccan IND-SIM-INT elements are extremely rare, and it is easy to find entire stories without them. When they are used, they may add ironical comment to the statement, e.g., in the following example from a story by @Amazigh-Chick:

Mohim Houda had shi 3 vriendjes gehad tijdens de relatie met Fouad.

'Well (muhim), Houda had had about (ši) 3 boyfriends during her relationship with Fouad' [chaima.nl; @Amazigh-Chick; 15/10/2012]

In humorous anecdotes, on the other hand, Moroccan IND-SIM-INT elements abound, e.g., in the two following posts from a topic about "weird and funny things that you experienced": 
(14) \{context: A girl going to the toilet in the dressing rooms of the school gym found a very big roll of toilet paper and started to mess around with it.\}

wat doe ik ik gooi het bhal chie freesby tegen wahed klasgenoot dr voorhoofd aan

'So what do I do? I throw it like (bhal) some (ši) frisbee on the forehead of a (waḩad) class mate.' [chaima.nl; @Lejla4195; 17/11/2010]

(15) \{context: The poster tells a number of funny things that happened at school that day.\}

En wa7id meisje doet fh7al shie lesbie \& knuffelde wa7id vriendin van mij en die vond dat kapot eng..

'And one (wahid) girl acts like (fhal) some (ši) lesbian and hugged a (wahid) friend of mine and she got terribly scared.' [chaima.nl; @MvrtjeSabrinaa; 12/11/2010]

Similarly, the following funny observation contains ižžən 'a' twice:

(16) \{context: This is the only post in a topic entitled Omg weet je wat ik heb gezien :/? 'O my God, do you know what I saw :|?'. Trimmed-back haircuts and Gucci clothes are characteristic of tough Moroccan young men.\}

[ ik zag de achterkant van een jongen. izjen lekkere opscheertje zo met stekeltjes, prachtige

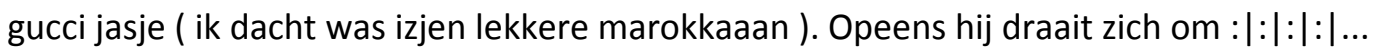

weet je wat ik zag?

EEEEEEEEN CHINEEEESSSS? niet te geloven!

'I saw the back side of a boy, a (ižžzn) nice trimmed-back haircut, with spiky hair, beautiful Gucci jacket (I thought it was a (ižžan) tasty Moroccan). All of a sudden he turns back $:|:|:|:| \ldots$

Do you know what I saw?

A Chinese? Can't believe it!' [chaima.nl; @temshoent; 17/10/2010]

\subsection{Key in contexts prone to misunderstanding}

Making out the key of a message depends to a large extent on the context of the utterance (or post, in our case). In the case of internet fora, this may be even more difficult than otherwise, especially in the starting sequence of the thread. Therefore, one expects elements that suggest the key of a thread to appear in its initial stages. This expectation is well born out by what one finds in chaima.nl. Moroccan elements such as the IND-SIM-INT elements under investigation frequently appear in the titles of the topics, thereby setting the key of the thread and attracting the right type of audience, e.g.:

(17) Wie o wie wilt er izjen gekke verhaal met mij schrijven?

'Who, o who, wants to write a (ižžən) nice story together with me?' [chaima.nl; @THEtakzbak; 30/4/2011]

(18) \{context: Topic title to a thread about fun in the snow.

Wajoow Ik heb izjen sneeuw MARTELING gekregen!!!

'Wow! (wayyaw) I was given a (ižžən) snow torture!' [chaima.nl; Kleintje_; 8/2/2007] 
(19) \{context: Title of a topic started at 5:30 in the morning. The topic starter unsuccessfully tries to set up a conversation on the forum as she is still not asleep.\}

iemand nog wakker wella?

'Anybody still awake, or (walla)?' [chaima.nl; \$Doekis\$; 17/6/2009]

Another sensitive context is where different keys are combined, for example when a serious topic about hair care is interspersed with more personal comments:

(20) \{context: The topic is about "how to get thicker hair". A long explanation about Islamic ways of achieving this is followed by a short interaction with personal feelings about hair, which is interspersed with Moroccan elements. Remark the expressive letter repetition in heyekkkkkkk.\}

@xlittleprincess: Ik heb heyekkkkkkk dik haar. Izjen bos krullen. 3la moeshpoesh. Wil het juist wat dunner!

@Laila15: Wauww ik wil jouw haar dan @ xlittleprinses ${ }_{\text {tbarkellah gewoon wees er trots }}$ op liefje! ik heb echt hayak dun haar ofzo.

‘@xlittleprincess: I have exceedingly (Səyyeq) thick hair. A (ižžən) head of curls. What a (Sla) mušpuš. ${ }^{11}$ I want it thinner!

@Laila15: Wow, then I want your hair @xlittleprinses Just great (tbarak-əl!lah), be proud of it my love! I have exceedingly (§əуyəq) thin hair or something like that. [chaima.nl; 2/2/2010]

In a similar advisory topic, about what to do against greasy hair, a certain advice is ridiculed in a friendly fashion using the Tarifiyt Berber tag nir (remark also the :lach: "laugh" emoji as a further marker of key):

(21)@tssmbenna: je haar wassen met afwas middel dreft ofzo klinkt gek maar het helpt echt !!!! $@$ @ini: Heb je deze tip uit Marokko nigh? ()

'@tssmbenna: Washing your hair with the dishwashing detergent Dreft or something like that, it sounds weird but it really helps!

$@$ mini: Did you get that advice from Morocco, or (niy)? $\Theta^{\prime}$ [chaima.nl; 18/12/2012]

A final example, also from a hair care topic, illustrates the difference between advisory language and less serious talk in a very clear way. The topic starter has chosen a deceptive title $I k$ hou van hem maar hij... 'I love him, but he...' in order to draw attention to a topic about how to get long curls. The key of the answers depends on whether they give advice on curls, or whether they comment on the title mismatch.

(22) wuhahahahh ik dacht chen grappige verhaal ofzo kom jij aan met je krulletjes hahah ${ }^{\mathrm{b}}$ als ik krullen doe gebruik ik meestal gwn Adrelon krulle mouse..

maar de krullen die je bedoelt wat mademOiselle al zei kn j beter met een krultang doen dat blijft mooi in model..

'Wuhahahahh I thought some (šan) funny story or the like, and there you come with your little curls hahah ${ }^{3}$. When I do curls, I normally simply use A[n]drelon curl mousse..

\footnotetext{
${ }^{11}$ The exact meaning of this expressive word has not been established.
} 
but the curls that you mean, like @mademOiselle already said, are better done with a curling iron, that keeps them in shape. [chaima.nl; @missmarokgirl4; 4/1/2011]

The poster is very careful to make clear that her first statement is not to be taken seriously. In addition to the use of šan, there are two representations of laughter (wuhahahahh and hahah) as well as the :lol: ("laugh out loud") emoji. The second emoji, :love:, which comes with the serious part of the post, is a further notice that the teasing is not meant to hurt anyone's feelings. One may also note that in the unserious part the diminutive krulletjes 'little curls' is used, while one has krullen 'curls' in the serious part.

\section{A note on other uses}

As stressed by Coupland (2007), social meaning - which includes key - is constructed in context, and the same linguistic phenomenon may be given different meanings in different contexts. This seems also to be the case of the Moroccan elements under consideration.

The corpus of this study was chosen because it neutralizes a number of possible factors, such as heritage group and age. In addition, the social conventions of the forum favor certain types of conversation, while they disfavor others. Most topics develop in a good-humored, sometimes serious, sometimes joking manner. Members treat each others as equals, and occasional rebukes (often concerning good Islamic behavior) normally take place in a friendly, sisterly way. As a result, serious verbal fights are rare, as are bragging and many other ways of speaking (or posting). Moreover, according to the forum rules, posts that do not comply to these conventions can be deleted by the administrators. Thus, one only rarely finds posts that are derisive; in such cases, Moroccan IND-SIM-INT elements may also appear, e.g.:

(23) fcontext: This is an excerpt from a longer comment on a lachrymose and fairly improbable story in the section Verhalen 'stories'. The poster suggests that the writer has made up everything, even though she pretends her story is autobiographic. The entire post has the same derisive character. It was deleted later, but is preserved in a quotation.\}

GOOOI JE KONT weg hahaha wesh had je niks te doen wella hahahahaa hahahahaha HAHAHAHAHHA je laat me echt lachen wollahilaah wahahahahaha grappemaakster

'Throw away your ass, hahaha waš (question marker) didn't you have anything to do, or (walla)? hahahahaa hahahahaha HAHAHAHAHHA you really make me laugh wallahilah ('by God!') wahahahahaha.' [chaima.nl; @WitteRoosje, quoted by @amiraaaaa5; 21/8/2007]

Derision is of course markedly different from the mild irony we saw in other posts, as it expresses total lack of solidarity with the addressee. There certainly is an element of humor in this type of text, however, even though it is rather meant to be appreciated by the wider audience (in this case the other members of the forum) than by the addressee.

Moroccan IND-SIM-INT elements are also quite frequently encountered on chaima.nl in stylizations (Jaspers 2006; Coupland 2007: 154) of the speech of unserious boys. ${ }^{12}$ This is especially clear in posts where girls pose as "tough" boys, a kind of humorous masquerade that turns up every now and then. The following is a small excerpt from a topic dedicated to this play:

\footnotetext{
${ }^{12}$ I will not dwell upon the ways in which Moroccan IND-SIM-INT elements are used to characterize protagonists in the dialogues contained in stories in the Verhalen sections. This question requires an investigation on its own, which takes into account the intricate interplay of different voicings (in the sense of Bakhtin 1981) found in such contexts.
} 
(24) \{context: The topic is initiated by @moussi08 which, according to the profile information, is another alias of @IJARMOUASSTYLO, a very prolific poster. The other poster, @nAadjuhH, uses her normal alias. Both posters are girls. Note the use of a number of other features: different types of expressive spelling, spellings suggesting lower class The Hague Dutch, and an abundance of funny emojis.

@moussi08: ewa hoe is het broeder?? 0

@nAadjuhH: Gaat goed HMDI alleen deze chik's hieró plakken als de Kénker! Wejo0w niet meer gezond man. Hoe gaat het met jou dan?

@moussi08: [...] goed hamdllheb je izjen relatie nigh??

@nAadjuhH: Izen? Ik heb er 20.

@moussi08: eyow. gataarr a broeder gatarrrr(@)

@nAadjuH: Je wait 't. le shek? Shien chick aan de haak geslagen nigh? $(90)$

‘@moussi08: So (iwa), how are you, brother?? @9

@nAadjuhH: I'm fine, thank God (I-hamdu l-illah) only those chicks here they stick like cancer! Wow! (wayyaw), not healthy, man! So how are you?

@moussi08: [...] Good, thank God (al-ḥamdu l-illah), do you have a (ižžən) relationship niz?

@nAadjuhH: One (ižžan)? I've got 20. (9)

@moussi08: Wow! (ayyaw). Awsome (xațar), o (a) brother, awsome (xațar) (@)

@nAadjuH: You know. So what about you ( $i$ šak)? Hooked up some (šin) girl, or (niy)? (9), [chaima.nl; 25/1/2008]

Similar stylizations may be found in topics that do not overtly imitate other people's talk. Thus in a thread about a small-scale riot in the Schilderswijk in The Hague, the starting sequence uses a number of Moroccan IND-SIM-INT elements and other ways of suggesting a "tough" person. After a witness of the event has made clear that it had only been a minor disturbance, the conversation calms down and goes on without further Moroccan IND-SIM-INT elements. I interpret the starting sequence as stylization: the posters, who otherwise present themselves as reasonable, good girls, take on a sensation-loving law-defying persona. The following fragment provides the first six posts of the thread.

(25)@kleintje: ik hoorde net van een mattie van mij op msn dat er gevecht was tussen mocro"s en ibe3ehes .Oorzaak politie had Marokkaanse jongen van 12 geslagen of zo iets .Vrouwelijke agente heeft baksteen tegen der face gehad ze is gelijk knock out gegaan wie heeft gezien of mee gedaan reporteer : $p$

@kehbiba: Whahahahahah, daar moesten we bij zijn daar gebeurt altijd wel wat

@kleintje: whhahaha jah man echt jammer

@ilie: inie wollah??

ik ga wel ff aan ishen jongen vragen of hij heeft gezien!! tfoee was ik er maar bij!!

@salima_m0slima: Dat hoorde k ook net.. ma k weej nie wat er precies is gebeurdd !

@salima_m0slima: Mn nicht woont daar en vertelde me net dat haar buurjOngen werd geslagen door politie..

En t0en had iezjen turkse jOngen baksteen gego0it op een agente.

'@kleintje: I just heard from a mate (mattie) of mine on msn that there had been a fight between Moroccans and the police (ibə५५aš). Cause: The police hit a 12 year old Moroccan boy or something like that. A policewoman got a brick on her face and got knocked out immediately. 
Anyone who saw it or participated, report! :p

@kehbiba: Whahahahahah, we should have been there! There's always something going on there.

@kleintje: Whhahaha, yes man, such a pity.

@ilie: Are you absolutely sure (literally: say lo!, ini wa!lah)?

I will ask a (ižžən) boy if he has seen it!!

Damn! (tfu) I wish I had been there!

@salima_m0slima: I just heard the same. But I don't know what happened exactly !

@salima_m0slima: My cousin lives there and she told me that a boy next door had been hit by the police.

En then a (ižžən) Turkish boy had thrown a brick at a female police officer.' [chaima.nl; 30/7/2007]

Moroccan IND-SIM-INT elements are thus used to stylize and stereotype "tough" speech by a certain type of boys and girls. This is not unique to girls' internet fora. Similar stereotypes occur in an entirely different genre, that can be found on video platforms such as youtube.com: funny sketches where a (mostly Moroccan Dutch) performer contrasts different types of behavior among different ethnic groups. The following sentence, imitating a criminal's way of speaking, comes from a sketch played by the popular video blogger @YousToub, a young comedian with a Moroccan background who mainly targets a Dutch Moroccan audience:

(26) \{context: Two young Moroccan Dutch burglars have broken into a bank and are searching for the safe; one of them switches on the light. He is rebuked in the following way:\}

Wat doe je de licht aan, a șaḥbi? Waš, waš ben je gek geworden, ma?

'What are you switching on the light, my friend (a șaḥbi)? Waš, waš (question marker) ben je gek geworden ma (interrogative tag)?' [https://www.youtube.com/watch?v=--XdmPRKVWo; 2:22-2:25]

One might be tempted to take "tough" speech as the basic meaning of the phenomenon under consideration, and interpet all instances of not-so-serious ironic keying as stylizations of tough boys' speech. However, a quick glance at some of the examples given above clearly shows that this is not the case. There is no way in which examples such as (1), (4), (5), (7) or (11) could be interpreted as emulating "tough talk".

This does not mean that there are no commonalities between an ironic humorous key and the "tough talk" stylized and stereotyped in the examples above. Both share a lack of seriousness, which makes them very different from simple informative or advisory texts. There is no doubt a lot of irony going on in "tough talk", even though it may be less self-directed than in many of the cases that were adduced before.

\section{Conclusion and outlook}

In this article, I have tried to show that the insertion of certain Moroccan function words in Dutch written internet discourse is commonly used to convey the key of the statement. In this usage, it functions as a way of elucidating the text, and the same person can use different keys without suggesting different identities or personas. Keying is thus different from stylization, as it does not "project personas, identities and genres other than those that are presumedly current in the speech event" (Coupland 2007: 154). In fact, when the same formal features occur in stylized discourse, they take different shades of meaning, mainly the characterization of "tough" speech. The meaning of the non-stylized key was tentatively established as ironic and/or not too serious. Only the study of a 
more diverse corpus of Moroccan Dutch texts could show if this characterization can be maintained, or that it should be extended and rephrased, for example in order to include abusive language such as in example (23).

As shown by Nortier \& Dorleijn (2008), Moroccan elements are also used by people with a non-Moroccan background in a kind of crossing (Rampton 1995). It is an open question to what extent this take-over of Moroccan features also implies taking over what they index, and if such discourse thus conveys the same social meanings as it does among the members of chaima.nl.

\section{References}

Androutsopoulos, Jannis (2006). Multilingualism, diaspora, and the Internet: Codes and identities on German-based diaspora websites. Journal of Sociolinguistics, 10/4, 520-547.

Auer, Peter (2005). A postscript: Code-switching and social identity. Journal of Pragmatics, 37, 403410.

Auzanneau, Michelle (2009). "La langue des cités " ? Contribution pour la libération d'un mythe. Adolescence, 2009/4 ( $\left.n^{\circ} 70\right), 873-885$.

Bauman, Richard (1975). Verbal art as performance. American Anthropologist, 77, 290-311.

Bakhtin, Mikhail (1981, originally 1934-1935). Discourse in the novel. In: The Dialogic Imagination. Four essays by M. M. Bakhtin. Edited by Michael Holquist. Translated by Caryl Emerson and Michael Holquist. Austin \& London: University of Texas Press, 269-422.

Boumans, Louis (1998). The Syntax of Codeswitching: Analysing Moroccan Arabic/Dutch Conversations. Tilburg: Tilburg University Press.

Boumans, Louis (2003). ZeYma. Een Noordafrikaans epistemisch partikel dat zich verspreidt. Gramma / TTT Tijdschrift voor Taalwetenschap, 10/1, 1-26.

Cheshire, Jenny, Jacomine Nortier \& David Adger (2015). Emerging multiethnolects in Europe. Queen Mary's Occasional Papers Advancing Linguistics, 33.

Cottaar, Annemarie, Nadia Bouras \& Fatiha Laouikili (2009). Marokkanen in Nederland. De pioniers vertellen. Amsterdam: Meulenhoff.

Coupland, Nikolas (2007). Style. Language Variation and Identity. Cambridge: Cambridge University Press.

Crul, Maurice \& Jeroen Doomernik (2003). The Turkish and Moroccan second generation in the Netherlands: Divergent trends between and polarization within the two groups. International Migration Review, 37/4, 1039-1064.

Darics, Erika (2013). Non-verbal signalling in digital discourse: The case of letter repetition. Discourse, Context and Media, 2, 141-148.

Dorleijn, Margreet (2016a). Introduction: Using written multilingual internet data in code-switching and language contact research. Journal of Language Contact, 9/1, 5-22.

Dorleijn, Margreet (2016b). Can internet data help to uncover developing preferred multilingual usage patterns? An exploration of data from Turkish-Dutch bilingual internet fora. Journal of Language Contact, 9/1, 130-162.

Dorleijn, Margreet \& Jacomine Nortier (2009). Code-switching and the Internet. In: Barbara Bullock \& Almeida Toribio (eds.), The Cambridge Handbook of Code-switching. Cambridge: Cambridge University Press, 127-141.

El Aissati, Abderrahman (2008). Amazigh, Arabic and Dutch in contact on an internet forum. In: Mena Lafkioui \& Vermondo Brugnatelli (eds.), Berber in Contact. Linguistic and Sociolinguistic Perspectives. Cologne: Rüdiger Köppe, 199-215.

Extra, Guus, Rian Aarts, Tim van den Avoird, Peter Broeder \& Kutlay Yağmur (2001). Meertaligheid in Den Haag. De status van allochtone talen thuis en op school. Amsterdam: European Cultural Foundation. 
Goffman, Erving (1974). Frame Analysis. An Essay on the Organization of Experience. New York: Harper \& Row.

Hinskens, Frans (2011). Emerging Moroccan and Turkish varieties of Dutch. Ethnolects or ethnic styles? In: Margret Selting \& Friederike Kern (eds.), Ethnic Styles of Speaking in European Metropolitan Areas. Amsterdam \& Philadelphia: John Benjamins, 101-129.

Hymes, Dell (1974). Foundations in Sociolinguistics. An Ethnographic Approach. Philadelphia: University of Pennsylvania Press.

Jaspers, Jürgen (2004). Tegenwerken, belachelijk doen. Talige sabotage van Marokkaanse jongens op een Antwerpse middelbare school. Een sociolinguïstische etnografie. PhD Antwerp.

Jaspers, Jürgen (2006). Stylizing Standard Dutch by Moroccan boys in Antwerp. Linguistics and Education, 17/2, 131-156.

Jaspers, Jürgen (2011). Talking like a 'zerolingual': Ambiguous linguistic caricatures at an urban secondary school. Journal of Pragmatics, 43, 1264-1278.

Jaworska, Sylvia (2014). Playful language alternation in an online discussion forum: The example of digital code plays. Journal of Pragmatics, 71, 56-68.

Kießling, Roland \& Maarten Mous (2004). Urban youth languages in Africa. Anthropological Linguistics, 46(3), 303-341.

Kossmann, Maarten (2000). Esquisse grammaticale du rifain oriental. Louvain \& Paris: Peeters.

Kossmann, Maarten (2013). The Arabic Influence on Northern Berber. Leiden \& Boston: E.J. Brill.

Kossmann, Maarten (2016). Yes/no interrogatives in Moroccan Dutch. In: George Grigore \& Gabriel Biţună (eds.), Arabic Varieties: Far and Wide. Proceedings of the $11^{\text {th }}$ Conference of AIDA, Bucharest 2015. Bucharest: Editura Universităţii din Bucureşti, 351-358.

Lafkioui, Mena (2008). Identity construction through bilingual Amazigh-Dutch "digital" discourse. In: Mena Lafkioui \& Vermondo Brugnatelli (eds.), Berber in Contact. Linguistic and Sociolinguistic Perspectives. Cologne: Rüdiger Köppe, 217-231.

Lampert, Martin \& Susan Ervin-Tripp (2006). Risky laughter: Teasing and self-directed joking among male and female friends. Journal of Pragmatics, 38, 51-72.

Matras, Yaron (1998). Utterance modifiers and universals of grammatical borrowing. Linguistics, $36 / 2,281-331$

Matras, Yaron (2009). Language Contact. Cambridge: Cambridge University Press.

Meel, Linda van (2016). The Roots of Ethnolects. A Sociophonetic Study in Amsterdam and Nijmegen. Utrecht: LOT.

Mettouchi, Amina (2008). Kabyle/French code-switching: A case study. In: Mena Lafkioui \& Vermondo Brugnatelli (eds.), Berber in Contact. Linguistic and Sociolinguistic Perspectives. Cologne: Rüdiger Köppe, 187-198.

Mourigh, Khalid (2015-2016). Unpublished corpus of sociolinguistic interviews with Moroccan youth in Gouda.

Nortier, Jacomine (1990). Dutch-Moroccan Arabic Code Switching among Moroccans in the Netherlands. Dordrecht: Foris.

Nortier, Jacomine (2016). Characterizing urban youth speech styles in Utrecht and on the Internet. Journal of Language Contact, 9/1, 163-185.

Nortier, Jacomine \& Margreet Dorleijn (2008). A Moroccan accent in Dutch: A sociocultural style restricted to the Moroccan community? International Journal of Bilingualism, 12/1-2, 125-142.

Nortier, Jacomine \& Margreet Dorleijn (2013). Multi-ethnolects: Kebabnorsk, Perkerdansk, Verlan, Kanakensprache, Straattaal, etc. In: Peter Bakker \& Yaron Matras (eds.), Contact Languages: A Comprehensive Guide. Berlin etc: Walter de Gruyter, 229-272.

Özcan, F. Hülya, Lian Malai Madsen, İlknur Keçik \& J. Normann Jørgensen (2015). Verbal teasing among young people in Køge and Eskeşehir. In: Jacomine Nortier \& Bente Ailin Svendsen (eds.), Language, Youth and Identity in the 21st Century. Linguistic Practices across Urban Spaces. Cambridge: Cambridge University Press, 231-246. 
Procházka, Stephan (2012). The main functions of theophoric formulae in Moroccan Arabic. STUF Language Typology and Universals, 75/4, 383-397.

Rampton, Ben (1995). Crossing: Language and Ethnicity among Adolescents. London \& New York: Longman.

Ruiter, Adrianus [Jan-Jaap] de (1989). Young Moroccans in the Netherlands: An Integral Approach to their Language Situation and Acquisition of Dutch. PhD Thesis, Universiteit Utrecht.

Shaw, Philip (2008). Spelling, accent and identity in computer-mediated communication. English Today, 24/2, 42-49.

Svendsen, Bente Ailin (2015). Language, youth and identity in the 21st century: Content and continuations. In: Jacomine Nortier \& Bente Ailin Svendsen (eds.), Language, Youth and Identity in the 21st Century. Linguistic Practices across Urban Spaces. Cambridge: Cambridge University Press, 3-23.

Yang, Guobin (2003). The Internet and the rise of a transnational Chinese cultural sphere. Media, Culture \& Society, 25, 469-490.

\section{Auteursinformatie:}

Maarten Kossmann

Leiden University Centre for Linguistics (LUCL)

Postbus 9515

2300 RA Leiden 